\title{
Costulariella, a new substitute name for Costularia Ju. Petrov et I. Gussarova (Laminariales, Phaeophyceae)
}

\author{
Nina G. Klochkova ${ }^{1, *}$ and Tatyana A. Klochkova ${ }^{2}$ \\ ${ }^{1}$ Kamchatka State Technical University (KamchatGTU), Petropavlovsk-Kamchatsky 683003, Russia \\ ${ }^{2}$ Department of Biology, Kongju National University, Kongju 314-701, Korea
}

Costularia Ju. Petrov et I. Gussarova, published in 1970, is a preoccupied name by Clarke, 1898 for a genus of monocotyledonous flowering plants in the family Cyperaceae (Magnoliophyta) and thus illegitimate. Costulariella nom. nov. is proposed as a replacement. The distribution and morphology of this little-known species are discussed.

Key Words: Costularia; Costulariella; Laminariales; morphology

In September 1967, the SCUBA divers of the research expedition supervised by Dr. Isabella Gussarova and organized by the Sakhalin Branch of the Pacific Scientific-Research Institute of Fishery and Oceanography (SahTINRO) have collected one unusual thallus of a laminariaceaen species from Simushir Island, Broughton Bay (Fig. 1), which was later described as a new genus, Costularia, by Gussarova and Petrov (1970). A single species was included in the genus, viz. Costularia kurilensis Petrov et Gussarova (1970: 87, Figs 1 \& 2).

Original diagnosis by Gussarova and Petrov (1970): Thallus large, composed of blade and stipe, attached by $12 \mathrm{~mm}$-diameter holdfast. Stipe short, $6 \mathrm{~mm}$ in length and $4 \mathrm{~mm}$ in diameter. Blade fan-shaped, almost spherical, greenish-brown in color, with black basal part, 30 $\mathrm{cm}$ in height and $43 \mathrm{~cm}$ in width, spirally twisted several times at its base, with numerous uneven folds positioned radially and raised to the blade's inner part. The folds were sometimes raised 3-5 $\mathrm{mm}$ above the blade surface, especially in its lower part. Long folds are extended from the blade basis to its middle part, some folds are dichotomously branched. Short folds 11-70 mm in length are

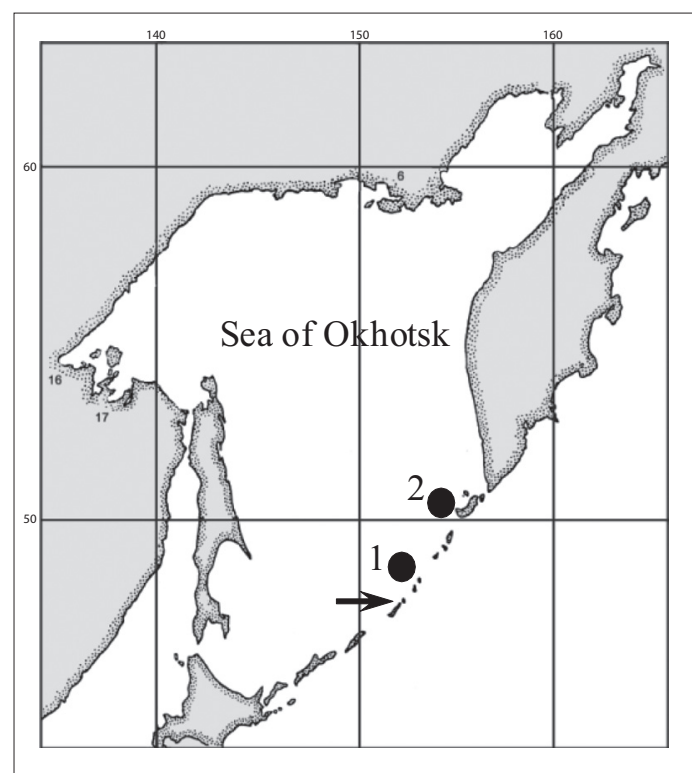

Type locality (Simushir Island)

Records of species distribution by Klochkova and Ogorodnikov (2006).

1:Yankich Island; 2: Paramushir Island.

Fig. 1. Map of currently known distribution of Costulariella kurilensis.

Received 12 October 2010, Accepted 11 November 2010

*Corresponding Author

E-mail:ninakl@mail.ru

Tel: +7-4152-300929, Fax: +7-4152-420501 (c) This is an Open Access article distributed under the terms of the Creative Commons Attribution Non-Commercial License (http://creativecommons.org/licenses/by-nc/3.0/) which permits unrestricted non-commercial use, distribution, and reproduction in any medium, provided the original work is properly cited. 

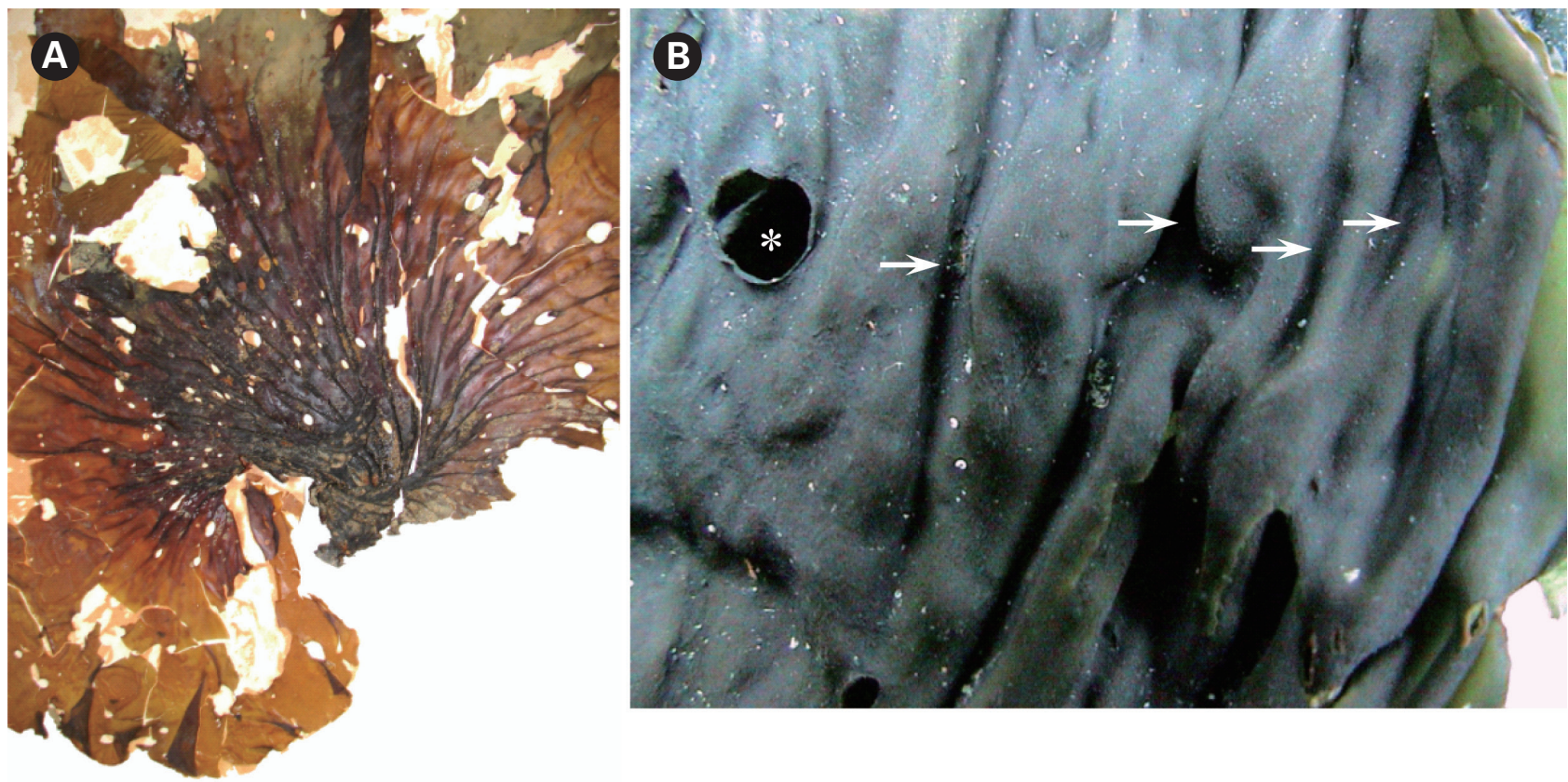

Fig. 2. Morphology of Costulariella kurilensis. (A) Fragment of type specimen re-photographed on 18 Sep, 2006. (B) Fragment of blade showing perforation with non-flattened edges (asterisk) and folds (arrows).

distributed in the middle and lower part of the blade and do not reach its base. The blade has several perforations with flattened edges, slightly bended to its inner surface. On the cross-section, the blade is $550 \mu \mathrm{m}$ thick; basal part is $830 \mu \mathrm{m}$ thick, medullar is narrow and $27-46 \mu \mathrm{m}$ thick. The blade becomes 1.5 times thicker on the upper edge of folds, mainly due to the increase of medullar thickness up to $180 \mu \mathrm{m}$. Medullar part is quite tight, made by cellular threads of large diameter, which sometimes do not differ from the parenchyma cells. Hyphae and cribriform tubules are not numerous. In the blade's upper layer, lens-shaped or sometimes globular shaped calcium oxalate crystals are seen. Lens-shaped crystals are flattenedconvex and adhere to the cell surface with flattened side. Individual crystals are formed singly in cells of blade's upper layer. When crystals grow large, the cells break. Crystals polarize light and can be dissolved in hydrochloric, acetic, and oxalic acids. Mucilage ducts and cryptostomes are absent in the blade. Sporangia are not known.

However, the name Costularia was already preoccupied by Clarke (1898: 274), who described a genus of monocotyledonous flowering plants of the family Cyperaceae (Magnoliophyta). A type has not been designated for Costularia Clarke (Farr and Zijlstra 1996); however, the genus is taxonomically accepted and currently includes over 20 species. Costularia Petrov et Gussarova is thus illegitimate. We propose a new replacement name,
Costulariella N. G. Klochkova et T. A. Klochkova, nom. nov.: Costularia Ju. Petrov et I. Gussarova in Novosti Sistematiki Nizshih Rastenii (News on Systematics of Non-vascular Plants), 7: 87-90, Figs 1 \& 2, 1970, nom. illeg., non Costularia C. Clarke in This.-Dyer, Flora Capensis (1898: 274). Apparently, Gussarova and Petrov (1970) wished to reflect morphological features such as a ribbed blade in the genus name (Latin: costatus).

Costulariella is typified by the only known species, viz. C. kurilensis (Ju. Petrov et I. Gussarova) N. G. Klochkova et T. A. Klochkova, comb. nov. - Costularia kurilensis Ju. Petrov et I. Gussarova, Novosti Sistematiki Nizshih Rastenii (News on Systematics of Non-vascular Plants), 7: $87-90,1970$. The type specimen was collected at the entrance of Broughton Bay from the depth of 25-27 m, in Simushir Island (Kuril Islands), on September 6, 1967 by Dr. I. S. Gussarova. It is currently housed in the Botanical Institute of Russian Academy of Sciences, St.-Petersburg and is in a fragile state (Fig. 2).

For over three decades, no new information, including pictures and numerical data, has been provided, although the species was cited in floristic lists of the Kuril Islands based on the first record in 1970 (e.g., Gussarova 1975, Zinova et al. 1980, Gussarova and Semkin 1986). Klochkova and Ogorodnikov (2006) provided additional information on the description and distribution of this species. They studied samples collected from Yankich Is- 
land and the southwest portion of Paramushir Island, located in the middle and northern portions of the Kuril Islands chain, respectively (Fig. 1). Yankich is a small island that has a bay $30 \mathrm{~m}$ in depth, which is a crater of Ushishir volcano. Ongoing underwater volcanic activity is a feature of the bay. C. kurilensis was collected at the bay's entrance from the depth of $25 \mathrm{~m}$ (Klochkova and Ogorodnikov 2006). In Paramushir Island, it abundantly inhabited rocky substrates at the depths of 15-18 m (Klochkova and Ogorodnikov 2006), forming approximately $70 \%$ of vegetative cover with a density of five plants per square meter (Ogorodnikov 2007).

Klochkova and Ogorodnikov (2006) reported that this species was perennial and even the oldest plants did not exceed $24 \mathrm{~cm}$ in height. Also, in old blades, the stipe was up to $6 \mathrm{~cm}$ in length and the holdfast was $2 \mathrm{~cm}$ in diameter. Calcium oxalate crystals were not only lens-shaped or globular, but polygonal or shapeless, and physodes with concentrated brown pigment (e.g., Petrov 1977, Klochkova et al. 2010) were found in peripheral cells of the meristoderm. As suggested, development of sporangial sori occurred on one side of the blade. More studies are necessary to fully amend diagnosis of this species.

C. kurilensis was placed in the family Laminariaceae and later was included in the family Costariaceae (Selivanova et al. 2007). The family Costariaceae was established based on conclusive molecular-phylogenetic evidence and included genera Costaria Greville, Dictyoneurum Ruprecht, and Thalassiophyllum Postels et Ruprecht (Lane et al. 2006). However, because attribution of additional taxa based solely on morphological similarity is unwarrantable, we propose that $C$. kurilensis should be treated as a member of Laminariaceae until conclusive molecular-phylogenetic evidence proves otherwise.

\section{ACKNOWLEDGEMENTS}

We thank secretary of the Editorial board of 'Novosti Sistematiki Nizshih Rastenii' (News on Systematics of Non-vascular Plants, St.-Petersburg, Russia), Dr. Vera M. Kotkova, for permission to use verbal translation of the diagnosis published in Gussarova and Petrov's paper (1970).

\section{REFERENCES}

Clarke, C. B. 1898. Cyperaceae. In Thiselton-Dyer, W. T. (Ed.)
Flora Capensis, Vol. 7. Reeve, London, pp. 149-310.

Farr, E. R. \& Zijlstra, G. 1996. Index Nominum Genericorum (Plantarum). Available from: http://botany.si.edu/ing/. Accessed on Nov 9, 2010.

Gussarova, I. S. 1975. Macrophytes of the subtidal zone of the islands Iturup, Urup and Simushir (Big Kuril Ridge). Novosti Sistematiki Nizshih Rastenii (News on Systematics of Non-vascular Plants) 12:111-118 (in Russian).

Gussarova, I. S. \& Petrov, Yu. E. 1970. A new genus and species of laminariaceaen algae from Kuril Islands. Novosti Sistematiki Nizshih Rastenii (News on Systematics of Non-vascular Plants) 7:87-90 (in Russian).

Gussarova, I. S. \& Semkin, B. I. 1986. Comparative analysis of macrophyte floras from some regions of the Northern Pacific using graph theoretical methods. Bot. Zh. (Leningrad) 71:781-789 (in Russian).

Klochkova, N. G. \& Ogorodnikov, V. S. 2006. Additional data on the description and distribution of the brown alga Costularia kurilensis. In Conservation of Biodiversity in Kamchatka and Coastal Waters. Materials of VII Int. Sci. Conf. Petropavlovsk-Kamchatsky, Kamchatpress, pp. 395-398 (in Russian).

Klochkova, T. A., Kim, G. H., Lee, K. M., Choi, H. G., Belij, M. N. \& Klochkova, N. G. 2010. Brown algae (Phaeophyceae) from Russian Far Eastern seas: re-evaluation of Laminaria multiplicata Petrov et Suchovejeva. Algae 25:77-87.

Lane, C. E., Mayes, C., Druehl, L. D. \& Saunders, G. W. 2006. A multi-gene molecular investigation of the kelp (Laminariales, Phaeophyceae) supports substantial taxonomic re-organization. J. Phycol. 42:493-512.

Ogorodnikov, V. S. 2007. Macroalgae of the northern Kuril Islands. Dissertation of Candidate of Biological Science. KamchatGTU, Petropavlovsk-Kamchatsky, Russia, 174 pp. (in Russian).

Petrov, Yu. E. 1977. The brown algae (Phaeophyta). In Gollerbah, M. M. (Ed.) The Life of Plants. Vol. 1. Moscow, Prosveszhenie, pp. 143-192 (in Russian).

Selivanova, O. N., Zhigadlova, G. G. \& Hansen, G. I. 2007. Revision of the systematics of algae in the order Laminariales (Phaeophyta) from the Far-Eastern seas of Russia on the basis of molecular-phylogenetic data. Russ. J. Mar. Biol. 33:278-289.

Zinova, A. D., Vozzhinskaja, V. B. \& Gussarova, I. S. 1980. Phytogeographic composition and characteristics of the benthic flora of the Sea of Okhotsk. Donnaya flora $i$ produktziya kraevykh morei (Benthic Flora and Production of the Boundary Seas). Nauka, Moscow, pp. 4-29 (in Russian). 